\title{
The transformation of Traditional TV to YouTube with Social Media and its Reflections in Turkey
}

\author{
Mihalis (Michael) Kuyucu \\ İstinye University Faculty of Economics, \\ Administrative and Social Sciences, İstanbul, TURKEY
}

\begin{abstract}
Today, YouTube attracts more people than the mostly-watched television channels due to its audience reaching up to one billion viewers every month. YouTube is the biggest video sharing social media network of the world and has started to challenge the traditional television media with the investments it makes recently. The platform does not broadcast only the videos shared by its users but also the special programs which it produces in its production studios and took one more step further than the traditional television media with the unique contents created. This study analyses the race of YouTube platform against the traditional television media in historical processes and the youth's habit of use of YouTube, a social media platform.
\end{abstract}

Keywords: New Media, social media, television, YouTube

\section{INTRODUCTION}

The term 'New Media' was coined in the 1970s with the information- and communicationbased researches and by the researchers who made social, psychological, economic, political and cultural studies. However, the meaning touched upon in the 1970s expanded together with the accelerated computer and internet technology of the 1990s and achieved a different dimension [1].

After the expansion of communication technologies, time and space limits were removed and internet broadcasting was developed. A new media type emerged as the traditional media was carried to the internet platform. This type of media, in turn, led to the emergence of a hybrid media product by simultaneously offering different traditional platforms such as radio, television and newspaper. The increase in internet connection speed made it possible for internet users to share big volumes of data more rapidly. Respectively; image sharing, audio sharing and video sharing became easier. The expansion of great volumes of digital data transfer and, thereby, of video sharing which requires high internet speed opened the way to video broadcasting through internet. After the expansion of video sharing, new platforms emerged which are engaged in video-based internet broadcasting.

Considering the developments in the television industry, it can be said that the media companies in Turkey made attempts especially as of web 3.0 period in order that television content can be watched on the internet. This study attempts to find answers to the question what kind of a management strategy is implemented in the new media platform by television broadcasting. Television contents are broadcasted on many new media platforms such as web, social media and video sharing websites. However, it is claimed that television companies confine themselves to transfer television contents and broadcast streams, which are broadcasted on the traditional media, to the new media platform, and that, therefore, the traditional television broadcasting repeats itself on the internet. In this context, it is asserted that television companies establish a graphical broadcast streaming on their website interfaces 
similar to the limitations and arrangements on the traditional media, and that they broadcast the contents in accordance with the similar limitations created on the internet platform.

\section{THE HISTORY OF TELEVISION IN TURKEY}

The first studies in Turkey for television broadcasting started in 1949 under Istanbul Technical University (ITU) in order to provide applied education to the students of High Frequency Technique Department. This attempt by ITU primarily aimed to establish an electronics laboratory where students could carry out studies and intended to create a system without desiring to proceed to regular broadcasting [2].

The first amateur Turkish television consisted of three chambers within ITU and the biggest of these chambers was used as a studio. Even though initiated as a practical lesson by the students, television in Turkey started its journey in 1952 as the images transmitted from ITU stations were watched on a screen. In the Turkish television history, the first person to use a camera, that is, the first cameraman was Prof. Dr. Adnan Ataman. The first television lightning was simply a projector placed on a stool. 'The first scenery' in the Turkish television history consisted of two curtains, one gray and the other brown. 'The first director', 'the first producer' or 'the first vision mixer' was consisted of the students and academic members of ITU [3].

It is said that when the first test broadcast was initiated in 1952 by ITU, there were 10 receivers in Istanbul and four of these were in ITU [4]. The studies for television broadcasting which started in the 1950s in Turkey started to prove fruitful in 1968. In consequence of the studies that backed the governmental power after the establishment of TRT (Turkish Radio and Television Association) in 1964, closed circuit broadcasting started in 1966 and regular broadcasting followed in January 31, 1968.

According to an agreement signed in 1963 between the Ministry of Foreign Affairs of Turkey and the Federal Government of Germany, a television training center was to be established in Turkey to train producers and technicians but, as per the Law no. 359, this arrangement was left to TRT which was found in May 1, 1964. In the course of its establishment, the first thing that TRT did was to request technical assistance from Germany in reference to the agreement concluded with the country. The first broadcast in Ankara became possible thanks to the $5 \mathrm{KW}$ transmitter presented by the Federal Government of Germany. The broadcast which was then made three days a week started to cover all the days of the week in 1974. The first broadcasts were made in CCIR European standards, on $111^{\text {th }}$ band and $5^{\text {th }}$ channel with $7 \mathrm{MHz}$ and $625^{\text {th }}$ line number, and news, sports, poetry, music, open session, movie, culture, education and children's programs were broadcasted.

The fact that the decision concerning broadcasting were not included to the second 5-year development plan because television broadcasting demanded a great budget and Grand National Assembly of Turkey (TBMM) was indifferent to such case caused the first test broadcasts to be more devoted and of quality while also forcing it to run with a limited budget. The broadcasts between 1968 and 1969 which were realized in every kind of impossibility were defined as "test broadcasts". According to the data of the fourth 5-year development plan, TRT broadcasts were being watched by $55 \%$ of the total population of Turkey in 1974 while this number reached up to $81,5 \%$ in 1977 [5].

In this period, TRT created programs that enlightened the country people and distributed television receivers to four villages of Ankara in February 1969 in order to ensure that these programs are watched. As part of these attempts, movies were shot in various rural areas of Anatolia for educating the people and these were broadcasted as television series. After the 
attempts proved successful, TV audience forms were produced and feedbacks were received [6].

A new period began in the Turkish political environment after the memorandum of Turkish Armed Forces on March 12, 1971. The autonomy of TRT that threatened the political power for a long time was eliminated in this period. Alteration was made to the article 121 of the constitution beside various other alterations and TRT was re-defined as "unbiased" by changing its "autonomous" status. Thus TRT became no more an autonomous institution and entered into the domination of the political power. In compliance with the constitutional change, certain articles of the Law no. 359 were altered and temporary articles were placed in place of them [7].

The military coup of September 12, 1980 became a milestone for radio and television broadcasts. Upon the impact of the coup, the features of the news, news programs, educational and cultural programs changed [8].

According to the article 133 of the Constitution of 1982 which was brought by September 12, "Turkish Radio and Television law no. 2954 is abrogated." This law did not only regulated TRT but also other broadcasts without the institution, and "High Council of Turkish Radio and Television" (RTYK) was established to be responsible for radio and television. Among the most significant responsibilities of this council was to nominate two candidates for the general management and twelve candidates for the board of management which actually consisted of six members, and to confirm broadcast programs. RTYK was liable to audit whether radio and television broadcasts complied with the laws and to inform TRT, the Prime Minister and the President with reports to be issued once in every three years.

As these developments occurred in Turkey, the political, economic and technological changes that swept the Europe were defined as deregulation and deeply affected Turkey. The monopolistic structure implemented by TRT continued until 1990. However, in the 1990s, private television broadcasting started in Turkey subsequent to the radical changes experienced. The place where private television broadcasting started in Turkey was Europe. In 1990, Turkish President Turgut Ozal and his son Ahmet Ozal became partners to Magic Box company, which had been established in Liechtenstein in 1989 by Cem Uzan and Kuno Frick. Though it was not legal, Turgut Ozal stated that there is no objection in foreign channels to broadcast to Turkey. Furthermore, in 1990, a channel which was also named as Magic Box started to send test signals through Eutelsat F5 satellite as Star 1 channel [9].

Color broadcasting came to Turkey in 1984. In 1985, technical directors and vision mixers took six weeks of training for color broadcasting and re-arranged the broadcast studios in Turkey. New vision utilization techniques were implemented and monitor set was established. While the world became smaller with television, the TRT monopoly was demolished illegally in Turkey, in 1994. The broadcast by the first private television channel of Turkey, Star, was followed by other national and local channels in the following years. Upon the Law concerning Radio and Television Institutions and their Broadcasts re-adjusted private radio and broadcast institutions on legal grounds [10].

\section{SOCIAL MEDIA IN TURKEY}

The rapid changes and developments in the digital world enhanced with technology have happened to be adopted swiftly also by Turkey. According to studies, internet users in Turkey 
spend 50 hours every month on virtual platforms, and watch video for 20 hours while they socialize for 28 hours.

According to the 2013 data of Domestic Information Technologies Utilization Research by Turkish Statistics Institute, 39,5\% of all the individuals between 16 and 74 was on the internet almost every day or at least once in a week. The individuals among the same age group who used the internet regularly in the same period was 91,6\%. There are more than 36 million people in Turkey who use the internet, says Financial Times. Webrazzi, a web page, states that Turkey is the second country after the USA to make the most check-ins on Foursquare. Thus, Turkey outdistances many countries such as Brazil, Russia, Indonesia, India and the United Kingdom. 31,10\% of the Turkish internet population uses Twitter and such figure makes Turkey the leading country of the world in Twitter use. The number of Turks who use Twitter is 11,337,505 people. Japan, the Netherlands, Venezuela, the Philippines and the United Kingdom follow Turkey as regards to this utilization. An academic member from Visual Communication Design Department of Fine Arts Faculty of Izmir University, Assoc. Prof. Dr. Mehmet Yakin asserts that such dense use of the internet in Turkey is a significant indicator for reflecting the technology conformance of Turkish people.

Ozkir presents the following numerical data in his study [11]. Social network websites are visited two billion times every day. 81\% of the users visit the profiles of their friends on social networks. $88 \%$ of the users watch online video. $49 \%$ of the internet users upload video to video sharing websites. The internet users approximately spend 13 hours a week on the internet while spending 8 hours on social networks. 42,9\% of the users also use Twitter. 30\% of the users gain access to social media through their mobile devices.

\section{THE REVOLUTION OF NEW TV: YOUTUBE}

YouTube is a video sharing website that always renews itself and carries out studies in order to ensure convenient use for its users. I decided to give information about YouTube by firstly touching upon its changing infrastructure up to now, the visuals and services. The changes on YouTube are as follows according to years;

The developments about YouTube in 2005; the history of YouTube start with the purchase of YouTube.com domain name in February 2005. The first video to be uploaded to the social network; the first video to be uploaded was a video shot by Jawed Karim, a founder of the website, showing him in San Diego Zoo and uploaded in April of the same year. The platform tested its beta version in May 2005. Sequoia Capital, an investment company, made 3,5-milliondollar investment to the social network in November of the same. Besides, Roelof Botha, a partner of Sequoia Capital, participated to the YouTube team. In July, the website gave opportunity to its users to give link to a video from their websites with an HTML code and to make research according to user names. Besides, the most popular, the most commented and the most favoured videos started to be listed. In the same month, HTML was used for the emails that are sent to the users. UTF-8 characters became supported in tags. Videos similar to that are watched started to appear next to comments. A simple application was developed in order to ensure video upload to Myspace pages. An improvement was made for sharing videos only with certain people. It became possible to share video with various environments such as "Family" and "Colleagues" that were placed under "My Friends" title. The users were granted the right to delete the comments they had made. HTML code was being improved and it was also allowed for uploaded videos to appear on other websites as a list. In August, video complaint button was developed. "Channels" section was added in order to ensure easy access to videos with similar content. E-mail notification preferences were developed. Voting choice was brought on by choosing starts from 1 to 5 . After this feature, desired videos were allowed 
to be closed for comments and voting. User profiles started to indicate how many videos a user watched on YouTube. In October, YouTube announced that it would present $4 \mathrm{gb}$ iPod Nano for those who could invite the most people to YouTube during November. During October, a person received iPod every day. "Play Lists" were developed within the same month. Subscription mechanism was developed. It was started to provide API for developers and to detail FAQ section. It became possible watch videos in full screen. In November, the first 3,5million-dollar investment support was realized. A week after the support, videos started to appear under "Prominent Videos" and "Today's Newest Videos" titles on the home pages of users. Response feature was added to the comments made by people in the comments section. Response feature was added to the comments made by people in the tags section. The necessary numbers to be entered was reduced from 3 to 1 in the tags section. The mostly watched videos were detailed and it became possible to gain access to the most watched videos of a day, week and month. In December, the user profiles, messaging section, blocking at least one user and reporting choices were added [12].

The developments on YouTube in 2006; In January, group choice was brought on. The users were enabled to create groups or to join groups. RSS feed support was added. "Friends" and "search" interfaces were renewed. About this time, YouTube made an announcement about video freezing issues and informed the users that YouTube had 45 terabytes of daily traffic. It was reported that improvements were continuing. In February, customized profiles were announced. The users became able to choose a video they want to feature on their profiles and to choose a YouTube URL as Youtube.com/user/username. It became possible to import contacts from Hotmail, Gmail, Outlook and other choices. During those days, the first step to income model was taken and a new membership type was announced as "Premium Content Owner". This system started to be recommended for professional structures such as television channels.

In February 2006, NBC applied to YouTube in order that the videos which contained images from "Lazy Sunday" and 2006 Olympics would be removed for which NBC possessed the copyrights. The next month, YouTube limited videos to 10 minutes in order to demonstrate its seriousness against copyright violations. However, the actual limit was 10 minutes and 58 seconds. Yet, such limitation was dodged by many users by dividing videos in series shorter than 10 minutes [13].

In March, YouTube became business partners with MTV2 channel. The series of Andy Milonakis Show started to be broadcasted on YouTube. The upload duration of videos was limited to 10 minutes for non-premium members. For the same, the file size limitation was confined to 100 megabytes. Having attracted negative reactions to 10 -minutes video restriction from some of the users, YouTube introduced "Director" program. Some users had Director accounts with this program. The members with this program were excluded from 10minutes upload limitation. Besides, these users also had certain privileges such as using their own logo on their video pages. In May, "Video Responses" improvement was made. This tool allowed the users to respond to a video with another video. In June, "Browsing History" was added. The users gained access to the videos they had watched previously.

In the summer of 2006, YouTube became one of the websites that demonstrated the biggest growth. On Alexa, YouTube left Myspace well behind in a list of the most popular websites and was listed as the $5^{\text {th }}$. It was reported in a study made in June 16, 2006 that 100 million videos were viewed in a day. According to the figures presented by Nielsen/Netratings, this website had approximately 20 million visitors every month. Of these, 44\% were women while 56\% 
were men and the age group that visited most was between 12 and 17. YouTube has a prominent fame in online video market. According to website Hitwise.com, YouTube dominates $64 \%$ of the online video market in the United Kingdom.

In July, "Terms of Use" were detailed. In this agreement, YouTube specified that the users had no right to sell the videos they uploaded. It was also shared with the users that YouTube would lose all the rights on a video in case a video is deleted by a user. In September, YouTube recognized the significant potential of amateur musicians' videos for the growth of the website and held a contest. The contest named "The YouTube Underground" allowed musicians to upload their works and let users vote these videos. 4 contestants with the higher points were granted Gibson Guitar, a New York journey in which transportation and accommodation were afforded by YouTube, chance of appearance on Good Morning America program, interview and chance of being featured in the prominent videos of YouTube. In December, YouTube Underground contest was concluded. The bands Greenland, Ostrich Head, Pawnshop and Maldroid became the winners of this contest. By that time, a controversy between YouTube and Myspace was settled, and Myspace let YouTube videos be played on its website [14].

The developments that took place on YouTube in 2007; In January, YouTube videos started to appear in the search section of "Google Video". Improvements were made to video responses and help center sections and channel appearances. Various shortcuts were added below videos such as Digg, Delicious and Furl in order to provide easy sharing. In February, videos were allowed to have music free-of-charge. Furthermore, certain privacy settings were developed such as receiving messages only from friends. In April, "Active Sharing" feature made it possible to see who viewed the same video at that moment. This feature that was offered as a choice was disabled if the users wished so. Comment limit was made flexible and no more security code was required after entering four security codes. A separate page was reserved for blocked users and the users were enabled to remove blocks. In June, similar videos section started appear next to embedded videos. In the same month, YouTube thumbnail became addable on Google. Google was a Google interface customization tool which was frequently used in those years. However, it was removed in the following years. YouTube also played an active role in presidency elections and allowed people to watch on YouTube.com/debates the duels of candidates which were broadcasted on CNN. YouTube informed its users that they could send their questions through this page. In the following days, YouTube Remizer tool was announced. This tool rendered it possible to make small editing to videos. Obama attended to YouTube Spotlight program with a video. Another important development that occurred in June was that YouTube opened its special sub-systems for 9 countries. There were websites opened for Brazil, France, Ireland, Italy, Japan, the Netherlands, Poland, Spain and the United Kingdom. In July, there was an important step taken for the users under 18. The users between 13 and 17 were requested to have parental permit for registering to the platform, and the users under 13 were rejected from entering to the social network. In August, clip arts were allowed to be added to videos. Within the same month, meetings were held among members in Los Angeles, New York and Berlin. Besides, a blog was created where the news of API for developers were shared. In September, "Comment" system was renewed. The comments were improved to be listed by date. The platform announced that comments also would be voted in the near future, and, in September, there appeared certain political attempts made. First of all, YouTube home page was coloured as green in order to support environmentalist movements. Besides, it was announced to the users that the videos sent by the victims of Darfur and Myanmar events were being broadcasted under the news category. Also, the platform which supported non-profit movements took a more concrete step in this regard and introduced "YouTube Non-Profit Program". This program which continued as of 2016 can be accessed through YouTube.com/non-profits. In October, Google's advertisement program "Google 
Adsense" were tried on some channels. Google Earth's YouTube integration was made. In November, video complaint system was developed. 17 sub-categories were added. "YouTube Uploader", a multiple video uploading tool, was developed. This tool was removed at a later time. Label recommendations started to come; education, science and non-profit content categories were added. A co-broadcasting was made with CNN. The users could send their questions to 8 Republican candidates during a program that was actually broadcasted on CNN but was watchable on YouTube. In December, search within channel feature was brought on. Music categories were expanded. RSS support was increased. Profiles photos within channel became possible [15].

The developments on YouTube that happened in 2008; In January, YouTube was provided with mobile support with m.youtube.com. The last comments were added to profile page. YouTube partner program was carried into effect in the United Kingdom. In February, home page customizations were increased. New sections were added such as recommendations, last shares by subscribers and the activities of friends. In March, a character counter was added to the comments section. World-famous SXSM festival was broadcasted on YouTube. Videos were provided with HD quality support. "The YouTube Awards" was declared to continue announcing that a contest was to be held and the winner would receive scholarship support for Vancouver Film School. Video analysis tool was opened to the access of the users. In April, search engine settings and video sharing preferences were improved. "YouTube Uploader" software was released for also Mac computers to follow PC. YouTube partner program was expanded to Japan, Australia and Ireland. Users were allowed to add videos to presentations prepared on "Google Documents". In May, Cannes Film Festival was broadcasted on YouTube. In June, a beta tool was released with which it was possible to add explanations to videos under "Video Annotations" title. The partner program was expanded to France and Germany. In July, forums were opened with help titles. A non-profit program was introduced in the United Kingdom. The partner program was expanded also to Brazil and Spain. In September, Paralympics that was held in Beijing, China was broadcasted on YouTube. In the same month, a journalism contest was held in collaboration with Pulitzer. Besides, Facebook and Twitter pages were created of the social network. Video uploading interface was renewed. In October, YouTube Live channel was introduced on which live presentations were held with celebrity. A new feature was introduced named "Deeplink" which helped to play a video from a particular moment and to refer to that certain time frame in comments such as "1:14 lol". In November, subtitle translations commenced enhanced by Google Translate support. Furthermore, "Sponsored Video" application started. A property was developed to feature videos in queries made with a keyword. In December, YouTube was integrated into a desktop software for Google Desktop, which was then a terminated project of Google. Improvements were made to ensure a secure use for children. Studies were conducted to find a solution to the legal issues which would arise out of music utilization in videos [16].

The developments on YouTube that took place in 2009; In January, Vatican opened a formal channel and appeared on YouTube. Video uploads to another video service of Google, 'video.google.com', was stopped. In March, video view counter was suspended at 301 views for a certain amount of time in order to reveal the possible frauds in video viewing numbers. A video analysis tool named YouTube Insight was developed and offered for use. Developments were made in order to unproblematically view the website on Windows Mobile and Nokia s60 devices. Upload bar was renewed. A new feature was brought which helped videos to be shared as tweets. An education project named "YouTube EDU" was initiated. It became easier to sign up with a Google account. In April, YouTube was awarded with The Peadybody Award, one of the oldest electronics awards. In the same month, a YouTube channel named "Fred" 
became the first channel to achieve 1 million subscribers. Click and buy feature was put into use in Canada, France, Ireland, Australia, Italy, Japan, New Zealand and Sweden. Subscription recommendations, user alternatives and uncopyrighted music recommendations were developed. In May, the users were allowed to send videos shot with mobile devices to their unique e-mail addresses defined for them and thus to share videos on YouTube. In June, "YouTube XL" section was created in order to offer a better interface for the users who possessed Sony PS3 and Nintendo Wii consoles. This section was also terminated in the previous years. Channel structure was updated and "Channel 2.0" mode was introduced. "Ask President Obama" was carried out. This enabled users to shoot a video of 20 to 30 seconds, upload to YouTube and ask their question to Obama. In July, video upload limit was increased from $1 \mathrm{gb}$ to $2 \mathrm{gb}$, and 3D and HD video support was brought. Certain details such as reference website, age range, sex and location took place among video analyses offered to the users. In September, Barack Obama made a speech to the members of the congress on YouTube. New developments brought about new sections such as friend recommendations and trend topics. In October, Nobel prizes and a U2 concert was broadcasted live on YouTube. Real time search feature was brought to comments. In November, this tool named "YouTube Direct" intended to establish a contact between journalists and citizens. Formal YouTube account of the Iraqi Government was opened. Videos was supported with 1080 p resolution. In December, a new tool was developed with which the users could find their Facebook friends and Yahoo contacts on YouTube. The total number of video views was added to member profiles.

The developments on YouTube in 2010; In January, HTML5 support commenced. Clips started to appear from videos uploaded during video uploading. In February, privacy preferences were improved. In March, prominent comments and new voting system were offered. The new voting system replaced scoring from 1 to 5 with "I Like This" and "I Dislike This" button. In April, language supports were increased. Sharing choices on Blogger and Buzz were added. In June, a tool was released that enabled online video editing. Once uploaded a video, it became possible with this tool to choose start and end points, merge a couple of uploaded videos and to add uncopyrighted music to them from "Audioswap" library. In July, 4K videos became supported. YouTube accounts were connected with Google accounts: it became possible to enter to the website with a Google account. A music-based sub-platform was established on 'YouTube.com/music'. Video upload time was increased from 10 minutes to 15 minutes for all users. In August, a series of new features were added. There were certain attributes that attracted attention among these: a home page integrated with Buzz which was social network initiative of Google, 'events around you' section and YouTube visuals that could be used by YouTubers in their videos. In the same month, YouTuber meetings were planned named as YTGathering. In September, the partner program was expanded to Argentina, Sweden, New Zealand and Czech Republic. Many new language supports were added such as Arabic and Romanian. A tool was developed to share YouTube movements automatically on Myspace. In November, 35 hours of movies were uploaded every minute. Chrome add-on was released for YouTube.

The developments that took place on YouTube in 2011; In January, a platform called Fflick was purchased which was known for its social media analyses. In March, YouTube opened a channel named "YouTube Person Finder" after the tsunami disaster in Japan and tried to help Japanese citizens who sought their relatives. In April, copyright endeavours were enhanced and the users who violated copyrights were forced to complete a virtual course named "YouTube Copyright School" where an online education was given about copyrights. In September, a sub-platform was opened for educators named "YouTube Teachers". A new tool was introduced where videos could be edited on 'YouTube.com/create'. In the same month, YouTube made an explanation against "urban myths". YouTube said, "Let's correct some urban 
myths" and added that 48 hours of video was uploaded every minute and it was not possible to watch all of them. Detailed explanations were made about incorrect beliefs which assumed that a video would be removed if continuous complaints were made to it or that a video uploader would be able to learn who the complainants were. In October, the movies on YouTube.com/movies were digress from the USA and were broadcasted in the United Kingdom. It became possible to sign in to YouTube with a Google account. In November, YouTube page was opened on Google Plus. An advanced analysis tool was released named YouTube Analytics. In December, a sub-panel was constituted about "Copyright" claims. Thus, the members gained right to practically manage the claims concerning the issues on copyrights. Video manager was developed. Certain parameters started to appear next to videos such as income status and privacy status.

The developments occurred on YouTube in 2012; In February, Google+ profiles started to take place on YouTube channel. In April, the interaction between Google Adwords and YouTube was reinforced. Approximately 500.000 enterprises were supported with free-of-charge advertisement that corresponded to 50 million dollars, in total. Therefore, it was intended to help enterprises to be accustomed with YouTube advertisements. In July, all the contents in Google Video database were transferred to YouTube, and it was announced that Google Video was to be closed on August 20. In August, a new YouTube application was developed for PlayStation 3, and, in September, YouTube application was introduced for iPhone and iPhone Touch. In October, YouTube announced tools for teachers to ensure a more convenient use. YouTube EDU was improved. The skydive of Felix Baumgartner, an Australian parachute jumper, from the border of the space was broadcasted live on YouTube. Besides, a target bar was added to "YouTube NonProfit Program" videos Thus a user could determine a viewing target for a video, a bar was established with which views were proportioned to this target and the bar became fuller as the views increased. In November, YouTube application was released for Nintendo devices. In December, the song "Gangnam Style" became the first video to achieve 1 billion views on YouTube [17].

The developments on YouTube in 2013; In May, the total video length uploaded each minute reached to 100 hours. The number of monthly visitors exceeded 1 billion. In June, the endeavours of LGBT communities were supported with \#ProudToLove hashtag. In September, "YouTube Music Awards" was announced.

The developments that occurred on YouTube in 2014; In March, a channel named Vice News was put into effect in order to follow the social events such as the Ukrainian movements and the protests in Venezuela. In April, YouTube started to support Xbox One. In May, a short online leaflet was published about the issues that resulted from internet speeds.

The developments that took place on YouTube in 2015; In February, a YouTube application special for children was released on Google Play and App Store. In June, a sub-platform was opened for gamers named YouTube Gaming. On this platform, the prominent videos from more than 25.000 gaming pages were showed. In October, YouTube Red was announced which was a significant development. YouTube for the first time promised the users in the US to watch adfree videos in return for 10 dollars. In March, the videos shot 360 degrees gained support and the users could rotate the view with arrow keys. YouTube achieved to sustain itself over the years with great developments and innovations.

The developments occurred on YouTube in 2016; the first YouTube Red Originals gala took place in February. "YouTube Red" is a charged membership that offers you an advanced and 
unrestricted experience on YouTube, "YouTube Music" and "Gaming YouTube". However, it is currently not available in Turkey. In March, "Gaming YouTube" was established. Live broadcast was allowed while playing games on mobile devices. In April, 360 degrees live broadcast was brought on. In June, YouTube Director application was released. In this application, enterprises could create their ad videos with their mobile phones. In August, it was announced that YouTube Red was collaborating with "YouTube Kids". Rio Olympics was announced to be broadcasted live on YouTube. In September, YouTube Go application was re-updated and it became possible for the users who experienced quota issues to save videos to their mobile phone memories where they could find unlimited internet and to watch them anywhere, they wanted. YouTube developed a program called "Heroes" in order to prevent "Terms of Service" violations. This was a worldwide community that consisted of voluntary contributors. It was designed to award the users. In October, it was announced that Famebit company was purchased, this purchase would increase the video content opportunities and that it would bring more income to online video community. In November, YouTube announced that it started to YouTube VR application and that it would be possible to watch 360 degrees virtual reality videos and HDR videos on Samsung SUHD and UHD TV through YouTube.

The developments on YouTube in 2017; In January, "Super Chat" application was released to ensure a more convenient chat with live streamers. It is possible for the users who use this application to chat for 5 hours at most. In March, YouTube TV was announced. This is an application on which traditional media channels can make live broadcasts on YouTube. In May, YouTube announced that it was redesigning the interface of the website. The developments of YouTube were tracked up to this point due to the delivery of my dissertation.

\section{THE INTERRELATION BETWEEN TV CHANNELS AND YOUTUBE}

The new media structuring of television broadcasting in Turkey have shown parallelism with the development of internet technologies and the expansion of social media platforms. In this sense, the 1990s became a significant period for the first internet infrastructure in Turkey and the first private television channels corresponded to this era. Within a few years after these private television channels commenced their broadcast lives, their websites started to appear on the internet. Consequently, such television channels started to avail of the platforms on the new media following the wide expansion of video sharing platforms, such as YouTube, as of the late 2000 s.

Table 1 : The Websites of Television Channels and YouTube Entry Years

\begin{tabular}{|l|c|l|c|}
\hline $\begin{array}{l}\text { Television } \\
\text { Channels }\end{array}$ & $\begin{array}{l}\text { Channel } \\
\text { Establishment } \\
\text { Year }\end{array}$ & $\begin{array}{l}\text { First Record Date of the } \\
\text { Website of Channel }\end{array}$ & $\begin{array}{l}\text { YouTube Channel } \\
\text { Opening Date }\end{array}$ \\
\hline ATV & 1993 & $1997(16$ October $)$ & 2014 \\
\hline Star1 & 1990 & $1998(18$ February) & 2011 \\
\hline Cine5 & 1993 & $1998(13$ May $)$ & N/A \\
\hline TGRT & 1993 & $1998(27$ June $)$ & 2011 \\
\hline Show TV & 1992 & $1999(12$ October $)$ & 2013 \\
\hline TRT & 1968 & $2001(18$ April) & 2015 \\
\hline Flash TV & 1992 & $2001(4$ December $)$ & \\
\hline
\end{tabular}

The television channels in Turkey started to continuously develop new social media utilization modes and content management strategies after the strengthening of the convergence between television broadcasting and internet technology. In this context, these methods which aim to ensure that contents are consumed by more users gradually constituted more complex digital content networks. 


\section{THE PROS AND CONS OF YOUTUBE}

We know that Social Media Tools have positive aspects as well as the negative ones. We attempted to compile some of these pros and cons.

\section{The Pros;}

- YouTube is applied to first in order to watch a favoured TV program.

- YouTube is used for listening to the songs favoured.

- YouTube is applied to instead of music channels on TV when a listener desires to watch the video clips of its favourite songs.

- YouTube is considered as an alternative for TV.

- YouTube is applied to for a program that was missed on TV.

- YouTube is believed to replace TV in the future.

- YouTube is availed of in order to watch the previous series of a serial.

- That videos that are on YouTube but are not showed on TV gives pleasure to the viewer.

- The videos on YouTube that attracts attention are shared on Facebook and Twitter.

\section{The Cons;}

- Personal information is copied without consent and personal data are altered.

- The secrets of commercial companies are disclosed.

- The users are misled due to videos prepared with false content.

- Manipulative contents are broadcasted in order to receive ads and sponsorship.

- Copyrights are disregarded.

- Contents that are contrary to public morality are created and spread.

- False blogs are created on behalf of a company in order to cause damage to that company.

- Contents are used without giving reference.

- Fake profiles are created by hiding real identities.

- Prejudiced contents are prepared by companies having paid for such contents in order to mislead their consumers.

- Spam videos are created.

\section{ASSESSMENT OPINION ABOUT YOUTUBE}

Michael Rosenblum, an online television producer and the founder of Rosenblum TV, said "The traditional TV concept is over. YouTube and internet video will not only impinge the rights of conventional broadcasting institutions but will also destroy them. YouTube has just started" and stressed that YouTube gains more strength every day before the conventional television broadcasting [18].

Even though the specialists assert that the conventional television loses power before the YouTube each day, Eric Schmidt of Google, who is the owner of YouTube platform, stated the following words about whether YouTube could ever replace television:

"The future is here. Television is already a part of the past. This is the condition today. It is not something that replaces another that you know of. We have to think about, program, help to and create new platforms for this completely new thing."

Eric Schmidt, Chairman of the Executive Board of Google, made a speech on May 5, 2013, and said "This already happened." about the prediction that internet videos would replace television. Schmidt specified that the future for YouTube was now and declared "If you believe 
that this number is much for YouTube, which attracts more than 1 billion visitors every month, just wait and you will see that this number will reach up to 6 or 7 billion" [19].

YouTube did not desire to be a platform that contents itself with the videos uploaded by its users but also created its unique contents. For this purpose, it opened state-of-the-art production studios in London, New York, Los Angeles and Tokyo.

YouTube explained that its target in production was "to achieve a better visual quality in an era when the internet became the main entertainment source for the young generation in many parts of the world". The platform shoots widely celebrated "Video Game High School" in these studios. For this serial that can only be watched on the internet and YouTube, Jimmy Wong said "This feature-length internet serial has the same quality with the programs that we see on television but has a greater production budget than they have." The program achieves a budget of 800.000 USD, in total, for the second season's shoots thanks to the donations of the viewers from 5 to 15 dollars. Wong stated, "The program has more than 3 million followers on YouTube and the age range of this wide group of spectators varies between 13 and 17". YouTube's initiative to create its own productions happened to be an important breaking point in the competition against conventional television. Thus, the platform also distinguished itself as also a production company that creates its own content.

In February 2013, YouTube declared that it was transformed into a television. Google announced in a statement that YouTube would replace television channels with an application that was intended to ensure compliance with television broadcasts. The first implementation on this subject was realized on Freesat, a joint venture by BBC (the state-driven radio and television institution in the United Kingdom) and ITV. Freesat, a set top digital satellite platform with a pre-paid system, accepted YouTube as a channel since March 2013.

The set top box platform with internet connection which hosts 180 channels and is used 1,7 million people in the United Kingdom accepted YouTube, and the website entered into competition with conventional television channels for the first time.

This platform created by social media thus will receive a market share from traditional television industry, will restrict them to diminish both economically and structurally and will be able to guide the world in all matters from social life to politics due to the global power it possesses. However, it should be mentioned that there will be also drawbacks due to the fact that YouTube will be the single player in online video market and new generation television. The shift in our attention from national and conventional televisions to video platforms reveals that it is necessary to create national video platforms. Nations should find their own national video platforms and guide the tendency towards online video market from global to national scale. Such an attempt will help to minimize the harm caused by the ideological contents which might arise due to YouTube, a global brand, with the help of nation-wide video platforms.

\section{CONCLUSION}

YouTube, the biggest video sharing platform of the world, achieved an immense growth in the eight years of its history since it was established in 2005. The video view numbers which indicated thousands previously increased up to a billion today.

This platform created by social media thus will receive a market share from traditional television industry, will restrict them to diminish both economically and structurally and will be able to guide the world in all matters from social life to politics due to the global power it possesses. However, it should be mentioned that there will be also drawbacks due to the fact 
that YouTube will be the single player in online video market and new generation television. The shift in our attention from national and conventional televisions to video platforms reveals that it is necessary to create national video platforms. Nations should find their own national video platforms and guide the tendency towards online video market from global to national scale. Such an attempt will help to minimize the harm caused by the ideological contents which might arise due to YouTube, a global brand, with the help of nation-wide video platforms.

\section{References}

AKCAY, H. (2011). Kullanımlar ve doyumlar yaklaşımı bağlamında sosyal medya kullanımı: Gümüşhane üniversitesi üzerine bir araştırma. İletişim Kuram ve Araştırma Dergisi, 33, 137 - 162.

ANKARA Ticari Hayat Gazetesi, YouTube televizyon ile olan savaşı kazandığını açıkladı, 06.05.2013

AZIZ, Aysel (1999). Türkiye'de Televizyon Yayıncılığı 'nın 30 Yılı (1968-1998). Ankara: Türkiye Radyo Televizyon Kurumu

BAY, Nurettin (2007). Radyo ve Televizyon Yayıncılı̆̆ı. Istanbul: Nüve Kültür Merkezi

Yayınları.

BOSTANCI, M. (2010). Sosyal Medyanın Gelişimi Ve İletişim Fakültesi Öğrencilerinin Sosyal Medya Kullanım Alışkanlıkları, Yüksek Lisans Tezi, Erciyes Üniversitesi Sosyal Bilimler Enstitüsü, Kayseri, 15, 46 - 47, 51-54, 64, $66,68,75$.

ERKUT, E. (2009). Sosyal Medya Araçlarının (Web 2.0) Kamu Hizmetleri ve Uygulamalarında Kullanılabilirliği. Türkiye Bilişim Derneği, 116, 96 - 101.

GULERARSLAN, A. (2011). İzleyici reklamla ne yapar internet reklamlarına yönelik kullanım ve motivasyonlar. Konya: Tablet Kitapevi, 166.

KIRIK, Ali Murat (2010). Etkileşimli Televizyon. Istanbul: Anahtar Kitaplar.

KIVANC, Halit (2002). Telesafir (Bizde Böyle Başladı). Istanbul: Remzi Kitap Evi

ONAT, F. (2009, 22 - 24 Ekim). Sosyal medyada İzmir ve İzmirlilik İzmirli Olmak Sempozyumunda sunuldu, Izmir.

OK, F. (2013). Ortaöğretim Öğrencilerinin Sosyal Medya Kullanım Alışkanlıkları ve Motivasyonları, Yüksek Lisans tezi, Fırat Üniversitesi Sosyal Bilimler Enstitüsü, Elazig

OZKIR, Y. (2014). Geleneksel bir medya aygitı olarak sosyal medya Kamu 'da Sosyal Politika 27, 38 - 43.

SUTCU, C.S. (2014). Yeni medya ve enformasyona özgürce ulaşma bağlamında gazetecinin bilişimciye dönüşümü. Yeni Türkiye Dergisi Özel Sayısı, Yeni Türkiye Stratejik Araştırmalar Merkezi, Ocak-Şubat, 56, 924 - 928.

TAMER, E.C. (1983). Dünü ve Bugünüyle Televizyon, İstanbul: Varlık Yayınları

TOKSARI, M., Murutsoy, M., Bayraktar, M. (2014). Tüketici algılarını etkileyen faktörlerde sosyal medyanın rolü: Niğde üniversitesi İ.I.B.F. örneği. Uşak Üniversitesi Sosyal Bilimler Dergisi, 7(4), 1 - 28.

YENGIN, H. (1994). Ekranın Büyüsü, İstanbul: Der Yayınevi.

WIRED Journal, YouTube, ABD, 2013, s.93

24 Saat Gazetesi, YouTube yeni stüdyolarla kalitesini arttıracak, Newspaper Published Date: 08.04.2013. 